\title{
Use of Buprenorphine in Treatment Resistant Depression
}

\author{
Ali Mahmood Khan ${ }^{1 *}$, Sukaina Rizvi ${ }^{1}$, Waqas Ul Haq ${ }^{2}$, Sohaib Siddiqui ${ }^{3}$, Danish Kherani ${ }^{2}$, Muhammad Mustafa \\ Ahmed $^{2}$, Ashraf Farooq Arain ${ }^{2}$ and Syed Kazim Raza ${ }^{4}$
}

${ }^{1}$ Kings County Hospital Center, USA

${ }^{2}$ Ziauddin University, Pakistan

${ }^{3}$ Ross University School of Medicine, USA

${ }^{4}$ Dow University of Health Sciences, Pakistan

Submission: April 25, 2018; Published: May 09, 2018

*Corresponding author: Ali Mahmood Khan, Kings County Hospital Center, NY, USA, Email: ali_mahmood_khan@hotmail.com

\section{Abstract}

This is a review article discussing the therapeutic effects of buprenorphine on treatment resistant depression. Treatment resistant depression is a term used in clinical psychiatry to describe depression that is not responding adequately to appropriate courses of at least two different antidepressants for major depression disorders. Buprenorphine is a partial agonist of mu and kappa receptors used for treating dependence or addiction.

\section{Introduction}

This research is being conducted to find out the result of the treatment of the drug buprenorphine on treatment resistant depression. According to a few researches being conducted, buprenorphine has proven to improve cases of treatment resistant depression.

\section{Discussion}

It is estimated that around 60-70 percent of patients with major depressive disorders have an inadequate response to the initial treatment that they are given [1-3]. Therapeutic strategies such as such as switching antidepressants and using adjuvant drug treatment have improved the condition but in 40 percent of cases patients remain symptomatic and fail to achieve full remission $[4,5]$.

Opioids are traditionally associated with pain, analgesia and drug abuse but it is clear that opioids have a major role to play in mood [6]. Buprenorphine is a derivative of the opioid alkaloid thebaine that is a more potent (25 - 40 times) and longer lasting analgesic than morphine. It appears to act as a partial agonist at mu and kappa opioid receptors and as an antagonist at delta receptors. Buprenorphine is used to treat dependence/addiction to opioids (narcotics). Since it is a partial agonist, this property of buprenorphine may allow it to have less euphoria and physical dependence and therefore have a lower potential for misuse
[7]. Usually the drugs used for major depressive disorders are Tricyclic Antidepressants (TCAs), Monoamine Oxidase Inhibitors (MAOIs) and Selective Serotonin Reuptake Inhibitors (SSRIs)/Serotonin-Norepinephrine Reuptake Inhibitor (SNRIs) but they had unacceptable side effects, drug to drug interactions and their onset was pretty slow and lacked efficacy [8].

According to researches done, buprenorphine may also benefit patients suffering from treatment resistant depression who have not responded to other medications. A research was performed on 50 patients in their midlife or were older adults. In this research patients were subscribed a low dose of titrated buprenorphine of $0.2-1.6 \mathrm{mg} /$ day for a period of eight weeks. Changes in depression, sleep, anxiety, quality of life and all positive and negative effects were assessed. Mean Depression Score (MADRS) was calculated at the beginning of the research which was at a baseline average of 27. After a period of 8 weeks, the calculated Mean Depression Score was calculated to be at 9.5 indicating a sharp decline in the score hence showing the positive effects of buprenorphine in treatment resistant depression. Patients also experienced less depressive effects like pessimism, sadness and also experienced improvement in learning and executive function. The result of this research resulted to be positive and stated that "Low-dose buprenorphine may be a novel-mechanism medication that provides a rapid and sustained improvement for older adults with TRD." [9]. 
In another research conducted, buprenorphine was given in combination with samidorphan to see what effect those 2 would have together. Patients were giving $2 \mathrm{mg} / 2 \mathrm{mg}$ of buprenorphine and samidorphan. After the research there was again a positive result compared to the placebo control and there were also no opioid withdrawal or treatment discontinuation side effects [10].

\section{Conclusion}

After reviewing a few researches and articles it can therefore be concluded that use of buprenorphine have promising results for the treatment of treatment resistant depression. The results obtained were positive and the drug buprenorphine itself has many advantages such as it is safe to use and there is less dependence on it and abuse potential is very low hence making it a very good drug to use in cases to treat treatment resistant depression.

\section{References}

1. Fava M (2003) Diagnosis and definition of treatment-resistant depression. Biol Psychiatry 53(8): 649-659.

2. Rush AJ, Gullion CM, Basco MR, Jarrett RB, Trivedi MH (1996) The Inventory of Depressive Symptomatology (IDS): psychometric properties. Psychol Med 26(3): 477-486.
3. Trivedi MH, Fava M, Wisniewski SR, Thase ME, Quitkin F, et al. (2006) Medication augmentation after the failure of SSRIs for depression. N Engl J Med 354(12): 1243-1252.

4. Rush AJ, Trivedi MH, Wisniewski SR, Nierenberg AA, Stewart JW, et al. (2006) Acute and longer-term outcomes in depressed outpatients requiring one or several treatment steps: a STAR*D report. Am J Psychiatry 163(11): 1905-1917.

5. Rush AJ, Trivedi MH, Wisniewski SR, Stewart JW, Nierenberg AA, et al. (2006) Bupropion-SR, sertraline, or venlafaxine-XR after failure of SSRIs for depression. N Engl J Med 354(12): 1231-1242.

6. Taylor GT, Manzella F (2016) Kappa Opioids, Salvinorin A and Major Depressive Disorder. Curr Neuropharmacol. 14(2): 165-176.

7. U.S. Food and Drug Administration (2002) Subutex and Suboxone approved to treat opiate dependence, FDA Talk Paper, T02-38.

8. Li W, Sun H, Chen H, Yang X, Xiao L, et al. (2016) Major Depressive Disorder and Kappa Opioid Receptor Antagonists. Transl Perioper Pain Med 1(2): 4-16.

9. Jordan F Karp, Meryl A Butters, Amy E Begley, Mark D Miller, Eric J Lenze, et al. (2014) Safety, Tolerability, and Clinical Effect of Low-Dose Buprenorphine for Treatment-Resistant Depression in Midlife and Older Adults J Clin Psychiatry 75(8): e785-e793.

10. Maurizio Fava, Asli Memisoglu, Michael E Thase, J Alexander Bodkin, Madhukar H Trivedi, et al. (2016) Opioid Modulation With Buprenorphine/Samidorphan as Adjunctive Treatment for Inadequate Response to Antidepressants: A Randomized Double-Blind PlaceboControlled Trial. Am J Psychiatry 173(5): 499-508.

\section{Your next submission with Juniper Publishers will reach you the below assets}

- Quality Editorial service

- Swift Peer Review

- Reprints availability

- E-prints Service

- Manuscript Podcast for convenient understanding

- Global attainment for your research

- Manuscript accessibility in different formats

( Pdf, E-pub, Full Text, Audio)

- Unceasing customer service

Track the below URL for one-step submission https://juniperpublishers.com/online-submission.php 